\title{
How Social Media are Successfully Transforming the Marketing of Local Street Food to Better Serve the Constantly-Connected Digital Consumer
}

\author{
Vita Briliana $^{1 *}$, Wasisto Ruswidiono ${ }^{1}$, Tita Deitiana ${ }^{1}$ \\ ${ }^{1}$ Trisakti School of Management, Kyai Tapa 20 Grogol, West Jakarta, 11440, Indonesia \\ *Corresponding author. Email: vita@stietrisakti.ac.id
}

\begin{abstract}
This paper aimed to deepen our understanding of the effect of the mobile-communication-technology usefulness, authenticity, historical nostalgia, and attitudes of Millennials towards food vlogger online reviews, in the context of purchase decisions involving local street food. YouTube has become the most popular video sharing platform almost all over the world. Many YouTubers compete to create various contents, including those related to food. Food-content creators on YouTube are usually called food vloggers, whose activities are reviewing food from a particular place. Data was collected using questionnaires distributed among Millennials who shop via mobile apps, and the purposive sampling technique was used. Finally, a total of 425 usable sets of data underwent data analysis process using Smart-PLS. The results show that mobile usefulness, authenticity, and historical nostalgia directly affect the attitudes of Millennials towards food vlogger online reviews. It appears that the local Indonesian street-food sellers need not be excessively worried about their sales during the COVID-19 pandemic, but they could try to be transformed digitally, follow health regulations procedures, and learn some promotional strategies such as inviting food vloggers to review their food and the eating experiences they offer.
\end{abstract}

Keywords: Mobile-communication-technology usefulness, authenticity, historical nostalgia, attitude, food vlogger

\section{INTRODUCTION}

The era of digital technology has influenced almost all sectors, including the Indonesian local culinary tourism, featuring street food. The COVID-19 pandemic in Indonesia has been impacting not only the people's health, but also their lifestyles, due to various policies that are being applied to manage the outbreak. The most striking changes can be seen in people's social lives and the economy. Now, people are relying more on digital technology to carry on with their social and economic lives amidst the policies of physical distancing and large-scale social restrictions (LSSR). With smartphones, they can still socialize through various media, including Instagram and YouTube, that facilitate marketing, social interactions, education, and entertainment, all without making physical contact. Online shopping is expected to continue in the future and become a new habit with strict health protocols. There are some challenges that must be overcome with cooperation among the government, micro, small and medium enterprises (MSMEs), local culinary tourism, and other supporting industries to increase the economic growth. Firstly, there needs to be an increase in public confidence to make safe purchases by complying with the procedures that have been implemented by the government to control the spread of COVID-19.
The total population of Indonesia was estimated to be 270.63 million people in 2019. The BPS Profile of the 2018 Millennial Generation stated that the Millennials are 33.75 percent of the total population. Millennials, also referred to the Millennial Generation or Generation Y, are the demographic cohort after the Generation X. The generations born between the 1980s and 2000s are often called Millennials by social researchers. This means that the Millennial generations nowadays are young adults whose ages range from 15 to 34 years old. These generations will reflect the image of the Indonesian nation whether it is a consumptive or productive nation [1].

An online news report published by [1] stated that most of the active internet users are the Millennial generations. From the Indonesian Telecommunication Statistics, [1] explained that the main purposes of using the internet are for social media and accessing information or news, with around 79.13 percent and 65.97 percent, respectively. Meanwhile, the other purposes of internet use, are for entertainment (45.07 percent), doing school work (25.87 percent), sending or receiving emails (21.10 percent), buying or selling goods and services online (10.82 percent), financial (5.08 percent), and others (12.84 percent). 
Although there is an increasing number of studies about the effects of vlogging on consumers, previous research has focused on the driving factors that influence consumer behavior. The focus has been on the results of reviews, using social media such as online communities and travel reviews [2], YouTube platforms including beauty vloggers [3] and food vloggers [4], tourism destination choices made using Instagram platforms [5], and perceptions of the credibility of the vloggers involved [6]. However, according to the author's knowledge, there is limited research that analyzes the effect on Millennial attitudes towards online food vlogger reviews, particularly during the COVID-19 pandemic. Therefore, this study aimed to fills the gaps in understanding the purchasing behavior of consumers of Indonesian local street food by examining the influences of mobile app use, authenticity of the atmosphere, historical nostalgia, and Millennial attitudes towards online reviews of food vloggers during the COVID-19 pandemic.

\section{LITERATURE REVIEW}

The Technology Acceptance Model (TAM) [7], developed with the aim of improving the understanding of the user acceptance testing (UAT) process, provides new theoretical insights into how to design and implement the successful information systems. In addition, it provides a theoretical model for a practical UAT methodology to enable system designers to evaluate a potential new system before the implementation. The TAM theory [8] explains that the intention of a person's behavior in using a system is determined by their belief in using the mobile application, and the extent to which they accept and believe that using the information system will improve performance.

The results of research by [4] revealed that attitude is a reaction or response from Millennials to food vlogger reviews on YouTube platform, which then prompt the individual behavior to buy. Attitudes are formed when a person evaluates an object or idea as favorable or unfavorable, and then develops emotional feelings and tendencies to take action regarding it [9]. Furthermore, the attitudes towards online reviews are the result of evaluating product or service attributes that are identified and felt, and the result is in consumers ultimately making a purchase decision. The results of previous research found that active consumers on social media, who have the same interests, often discuss and share experiences when considering purchasing decisions in relation to traveling solo [10] [11] [12], food vloggers [4], beauty vloggers [3], and information sources in the hospitality industry [13].

[4] stated that online food vlogger reviews on the YouTube platform affect the attitudes towards buying behavior of the Millennial generation with regard to Indonesian local street food. Basically, when consumers search for information on social media, they try to understand, and are ultimately interested in buying, the advertised product [3]. Reviews from other consumers are external stimuli that can influence consumers to buy a product. Furthermore, reviews from food vloggers on YouTube platform can go viral, spreading more widely and quickly, so the potential impact on consumer behavior can be stronger than that of advertising.

Mobile usefulness is defined as the extent to which mobile application users use information retrieval whenever and wherever [11] [14]. The use of mobile applications greatly impacts the tourists traveling alone and requires as much information as possible, such as location, restaurant operating hours, prices, delivery services and so on [11] [15]. Recent research by [4] revealed that Millennials are looking for information about street food on YouTube, searching for and finding street food locations with the mobile application as a tool that is easy to use. Nowadays, more and more people understand how to use the required application so that it satisfies their needs, which in turn leads to a positive attitude towards doing this [4] [14] [16]. According to [17], historical nostalgia relates to the memory structures shared, inherited, and even built by a group or society. So, this basically comes from a historical period that is not experienced by today's consumers, because they had not been born at that time [18]. Stern [19] noted that the imagination, honesty, and empathy are needed when generating historical nostalgia. Past studies have also proven that nostalgia is a motivation for travelling [19]. During YouTube reviews of local Indonesian street food, the food vloggers will usually discuss where the food and drinks come from, when the hawkers started selling them, and the origin of the recipes. In the context of this study, historical nostalgia is defined as a very effective marketing tool that elicits various consumer responses. Previous research revealed that historical nostalgia and attitudes are related [17] [20].

A study by [21] revealed that authenticity derives from a story that provides meaning related to the place and food culture that is inherent as a cultural representation. Indonesia is comprised of many unique cultures and ethnic groups. This uniqueness is often referred to authenticity [22], which denotes the qualities associated with a wide variety of authentic foods and cuisines specific to a particular location or place. [23] stated that the culinary heritage of a destination identifies the character and mentality of the community in the type of food and the way it is eaten. In the context of this study, authenticity can be defined as a customer's evaluation of the authenticity of the quality of the range of cuisine that is a feature of a particular place. Research has shown that authenticity significantly influences consumer behavioral intentions [21] [22] [24] [25].

\section{RESEARCH METHODOLOGY}

The research framework can be seen in Figure 1 as follow. 


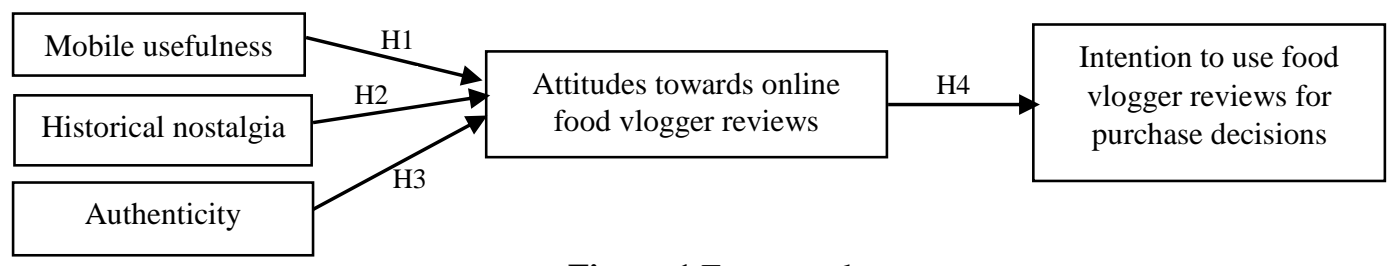

Figure 1 Framework

$\mathrm{H}_{1}$ : A positive relationship exists between mobile usefulness and attitudes towards online food vlogger reviews.

$\mathrm{H}_{2}$ : A positive relationship exists between historical nostalgia and attitudes towards online food vlogger reviews.

$\mathrm{H}_{3}$ : A positive relationship exists between authenticity and attitudes towards online food vlogger reviews.

$\mathrm{H}_{4}$ : A positive relationship exists between attitudes towards online food vlogger reviews and the intention to use food vlogger reviews for purchase decisions.

The sample size of this study was 425 . The respondents used in this study are consumers of local Indonesian street food in Jakarta, Indonesia. The study was conducted in September 2020 through online surveys, which was appropriate considering the vlogging context. Screening questions were used to ensure that the respondents who met the criteria were the Millennials who use YouTube; consumers who regularly access reviews of local Indonesian street food by food vloggers (e.g. Nex Carlos, and Boengkoes), and who routinely buy local Indonesian street food, particularly on the recommendations by a food vlogger.
A questionnaire using a seven-point Likert scale was used to gather data for each construct of the research model. Based on previous studies, the measurement scale items used in this study have already been validated in previous research [4] [14] [15] [17].

\section{RESEARCH RESULTS AND ANALYSIS}

The respondents' profiles revealed that the majority were male $(51 \%)$, between 19 and 23 years old $(47 \%)$, students and working (41\%). Most respondents $(66.1 \%)$ admitted to routinely viewing the presentations by food vloggers, especially Nex Carlos and Boengkoes, just for enjoyment, and buying street food after watching the food vlogger reviews. The frequency of buying local Indonesian street food was more than seven times a week (53\%).

\subsection{Goodness-of-Fit Measures}

Confirmatory factor analysis (CFA) was applied to test the validity and reliability of data using SmartPLS 3.0 software to assess the model in two stages, fulfilling the criteria suggested by [26].

Table 1 Summary Result of the Measurement Model and Convergent Validity

\begin{tabular}{|c|c|c|c|c|c|}
\hline \multirow{2}{*}{\multicolumn{2}{|c|}{ Attitude toward online food ylogoer reviews - adanted from [4] [100] }} & Loading & $\mathrm{CR}$ & AVE & $\alpha$ \\
\hline & & \multicolumn{4}{|c|}{ Attitude toward online food vlogger reviews - adapted from [4] [10] } \\
\hline $\mathrm{AT}_{1}$ & Online food vlogger reviews help my decision-making. & 0.786 & 0.803 & 0.674 & 0.521 \\
\hline $\mathrm{AT}_{2}$ & Online food vlogger reviews are informative. & 0.738 & & & \\
\hline $\mathrm{AT}_{3}$ & $\begin{array}{l}\text { Online food vlogger reviews are a good method of finding out } \\
\text { good things about food and beverages. }\end{array}$ & 0.769 & & & \\
\hline $\mathrm{AT}_{4}$ & $\begin{array}{l}\text { Online food vlogger reviews are a good method finding out bad } \\
\text { things about food and beverages. }\end{array}$ & 0.761 & & & \\
\hline \multicolumn{6}{|c|}{ Historical nostalgia - adapted from [17] } \\
\hline $\mathrm{H}_{1}$ & I can experience a time before I was born. & 0.734 & 0.850 & 0.655 & \\
\hline $\mathrm{H}_{2}$ & I can relive the time when I was young. & 0.761 & & & \\
\hline $\mathrm{H}_{3}$ & The food can help me imagine how previous generations lived. & 0.883 & & & \\
\hline \multicolumn{6}{|c|}{ Mobile app usefulness (M) - adapted from [15] } \\
\hline $\mathrm{M}_{1}$ & $\begin{array}{l}\text { Using the _- mobile app helps me complete my tasks more } \\
\text { quickly. }\end{array}$ & 0.734 & 0.782 & 0.647 & \\
\hline $\mathrm{M}_{2}$ & Using the __ mobile app facilitates the completion of my tasks. & 0.760 & & & \\
\hline $\mathrm{M}_{3}$ & Overall, the __ mobile app is helpful. & 0.813 & & & \\
\hline \multicolumn{6}{|c|}{ Authenticity (A) - adapted from [21] [25] } \\
\hline $\mathrm{A}_{1}$ & $\begin{array}{l}\text { While viewing the food vlogger review, I felt related to the } \\
\text { history of local Indonesian street food. }\end{array}$ & 0.713 & 0.803 & 0.674 & \\
\hline $\mathrm{A}_{2}$ & $\begin{array}{l}\text { During the visit, I felt related to the history of local Indonesian } \\
\text { street food. }\end{array}$ & 0.855 & & & \\
\hline $\mathrm{A}_{3}$ & $\begin{array}{l}\text { The local Indonesian street food contributed to my sense of } \\
\text { belonging to Indonesian culture. }\end{array}$ & 0.917 & & & \\
\hline
\end{tabular}




\begin{tabular}{|l|l|l|l|l|l|}
\hline $\mathrm{A}_{4}$ & I like the way the local Indonesian street food was designed. & 0.921 & & \\
\hline $\mathrm{A}_{5}$ & $\begin{array}{l}\text { After buying local Indonesian street food, I feel that it means a lot } \\
\text { to me. }\end{array}$ & 0.891 & & \\
\hline Intention to use food vlogger reviews for purchase decisions - adapted from [8] & 0.747 & 0.753 & 0.606 & 0.535 \\
\hline ITS $_{1}$ & $\begin{array}{l}\text { After viewing the food vlogger review, I am willing to purchase } \\
\text { the food and beverages being advertised. }\end{array}$ & 0.759 & & & \\
\hline ITS $_{2}$ & $\begin{array}{l}\text { After viewing the food vlogger review, I would consider } \\
\text { purchasing the advertised food and beverages. }\end{array}$ & 0.79 & \\
\hline
\end{tabular}

Table 2 Fornell-Larcker_Criteria

\begin{tabular}{|c|c|c|c|c|c|}
\hline & A & AT & H & IT & M \\
\hline A & $\mathbf{0 . 8 2 1}$ & & & & \\
\hline AT & 0.301 & $\mathbf{0 . 6 5 3}$ & & & \\
\hline H & 0.483 & 0.361 & $\mathbf{0 . 8 1 0}$ & & \\
\hline IT & 0.260 & 0.188 & 0.174 & $\mathbf{0 . 7 7 9}$ & \\
\hline M & 0.260 & 0.354 & 0.200 & 0.144 & $\mathbf{0 . 7 3 9}$ \\
\hline
\end{tabular}

Table 3 Hypothesis Testing Results

\begin{tabular}{|c|c|c|c|c|c|c|c|c|}
\hline & & Path & & Beta & Standard error & t-value & $p$-value & Supported \\
\hline $\mathrm{H}_{1}$ & $\mathrm{M}$ & $\rightarrow$ & AT & 0.328 & 0.046 & 7.096 & 0.000 & Yes \\
\hline $\mathrm{H}_{2}$ & $\mathrm{H}$ & $\rightarrow$ & AT & 0.289 & 0.293 & 6.041 & 0.000 & Yes \\
\hline $\mathrm{H}_{3}$ & $\mathrm{~A}$ & $\rightarrow$ & AT & 0.091 & 0.046 & 1.981 & 0.048 & Yes \\
\hline $\mathrm{H}_{4}$ & $\mathrm{AT}$ & $\rightarrow$ & IT & 0.495 & 0.050 & 3.936 & 0.000 & Yes \\
\hline
\end{tabular}

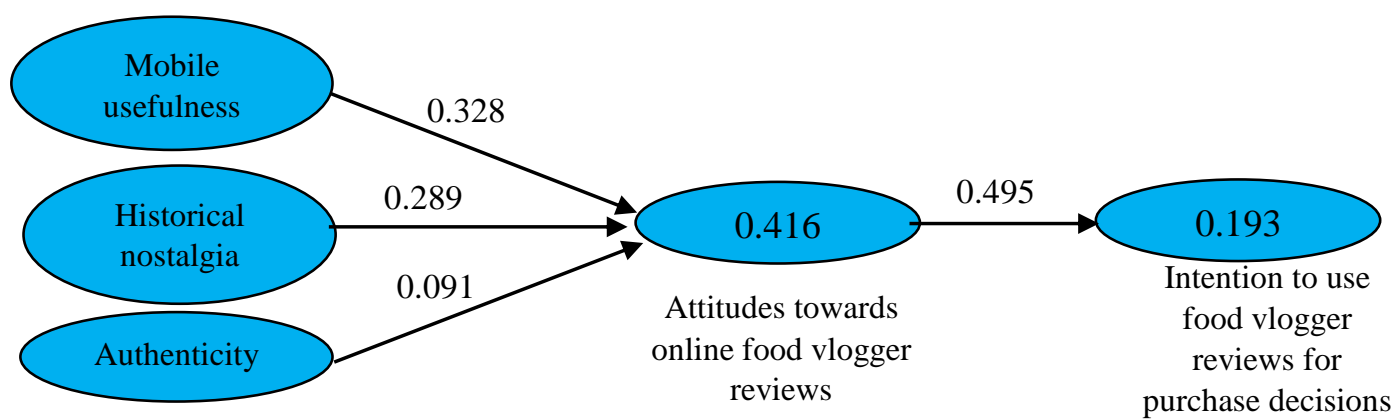

Figure 2 Measurement model of the intention to use food vlogger reviews for purchase

The analysis of construct validity was done by testing the composite reliability, discriminant validity and convergent validity [27]. The results showed the Cronbach's Alpha values of more than 0.7 , which indicates internal reliability and the consistency all constructs [26]. The results for reliability and average variance extracted (AVE) in this study demonstrated satisfactory convergent validity. The results show no collinearity issues between the variables, since the values of the variance inflation factors (VIF) were all at the conventional level from 0.2 to 5.0. The results for discriminant validity of the construct are demonstrated in Table 2, which is in fact the FornellLarcker criterion matrix. The matrix shows that validity is achieved, because the measurements within the columns are not above the square-root of the AVE [26].

\subsection{Structural Model Outcomes}

Hypothesis results are shown in Table 3. All hypotheses, $\mathrm{H}_{1}, \mathrm{H}_{2}, \mathrm{H}_{3}, \mathrm{H}_{4}$, were supported because the values of $\mathrm{t}$ statistics are above 1.96 [27]. These results are consistent with previous studies [4] [17] [14] [15].

\section{CONCLUSIONS AND MANAGERIAL IMPLICATIONS}

The uncertainty about when the COVID-19 outbreak will end, has made many business people turn to the digital realm. Their goal is clear: the survival of their businesses. Changes in consumer lifestyles have them buying, receiving, and consuming goods, and enjoying services or experiences in a way that is different from those before the virus occurred, because now they need to make as little contact with other people as possible. Some make purchases online because of the speed and convenience 
when they shop this way. Using mobile apps provides consumers with benefits they receive, that are greater than the cost or effort involved. So, the usefulness of mobile apps has a positive effect on consumer behavior after watching an online food vlogger review that describes how food and drinks are ordered and digital payments are made easily at the buyer's location. As entrepreneurs, the owners of small street-food businesses must be optimistic in facing this situation and finding the right solutions, in much the same way as culinary business players who are making innovations with ready-to-eat or ready-to-cook food, which can be marketed through social media or the e-commerce marketplace. So now, small business actors, especially local street hawkers, have to quickly adapt to enter the digital realm in a relatively short time, as the right strategy to keep the business afloat. Apart from having to accept orders via a digital platform, digital payments on delivery are made in collaboration with the delivery service platforms.

The authenticity of both the food and the atmosphere is communicated through inheritance and connections with past events, resulting in the continuation of a myth about a particular style icon's production process [21] [25]. Local Indonesian food lovers, in order to be able to buy and enjoy the taste of authentic snacks, usually look for the information on social media, i.e Instagram and Facebook [20], or watch the online food vlogger reviews that recommend authentic flavors on YouTube platform [4]. These impressions, combined with historical nostalgia, have a significant positive effect on consumer attitudes. Watching online food vlogger reviews can evoke emotions which become behavioral influences that promote what [6] refers to as, "a place in a time you can only imagine", thus evoking memories and feelings from the past. The taste of authentic food and a pleasant atmosphere give rise to the experiences that remind people of the past or a beautiful childhood, causing the Millennial generation to engage in buying behavior.

The purveyors of Indonesian local street food need to take advantage of the social media phenomenon (i.e. the YouTube platform), as this is an opportunity for them to innovate and increase customer perceptions of their products. They can collaborate with YouTubers to further help them gain recognition and revive memories of authentic tastes that may have been forgotten. This can be done by inviting food vloggers to taste the authentic food on offer and asking them to provide suggestions that could develop their business. In addition, this study shows that YouTube food vloggers must strive to provide honest product reviews, as they greatly influence their viewers' purchasing decisions.

In addition, the sample area of this study covers only one area, namely Jakarta. This was done in order to obtain better results in accordance with the cultural variations in local Indonesian street food, so that Indonesian culinary tourism could be promoted both domestically and internationally. If food-vlogger subscribers rely on recommendations from good reviews, then they are more likely to follow and take advantage of future street food and location recommendations. Therefore, future studies should refine our theoretical model by including other factors such as trust, pricing, which may also influence the behavior of Millennials.

\section{ACKNOWLEDGMENT}

We would like to express our deepest gratitude to the Ministry of Research, Technology, and Higher Education of the Republic of Indonesia, for its short-term grant that supported this research.

\section{REFERENCES}

[1] Statistics Indonesia, https://www.bps.go.id/, accessed 16 Oct 2020. Retrieved from https://bandungkota.bps.go.id/news/2020/01/07/15/sens us-penduduk-2020--sensus-era-digital---.html

[2] Mohammad Reza Jalilvand, Neda Samiei. 2012. The impact of electronic word of mouth on a tourism destination choice: Testing the theory of planned behavior (TPB). Internet Research, Vol. 22 Issue: 5, pp.591-612,

https://doi.org/10.1108/10662241211271563

[3] Matthew Tingchi Liu, Yongdan Liu, Lida L. Zhang. 2019. Vlog and brand evaluations: the influence of parasocial interaction. Asia Pacific Journal of Marketing and Logistics, https://doi.org/10.1108/APJML-01-2018-0021

[4] Briliana, V; Ruswidiono, W; Deitiana, T. 2020. Do Millennials believe in food vlogger reviews? A study of food vlogs as a source of information, Journal of Management and Marketing Review, 5(3), pp. 170 178. https://doi.org/10.35609/jmmr.2020.5.3(5)

[5] Briliana, V. 2019. What do Millennials see in Indonesia? An analysis of Generation Y travel intentions through Social Media. African Journal of Hospitality, Tourism and Leisure, GCBSS Special Edition. ISSN: 2223-814X. https://www.ajhtl.com/uploads/7/1/6/3/7163688/article_ 10_se_gbcss_2019.pdf

[6] Keng-Chieh Yang, Chia-Hui Huang, Conna Yang, Su Yu Yang. 2017. Consumer attitudes toward online video advertisement: YouTube as a platform, Kybernetes, Vol. 46 Issue: 5, pp.840-853, https://doi.org/10.1108/K-03-2016-0038

[7] Davis, F.D. 1989. Perceived usefulness, perceived ease of use, and user acceptance of information 
technology, Management Information System Quarterly, Vol. 13 No. 3, pp.319-340.

[8] Sony Kusumasondjaja, Fandy Tjiptono. 2019. Endorsement and visual complexity in food advertising on Instagram. Internet Research, https://doi.org/10.1108/IntR-11-2017-0459

[9] Kotler, Philip and Kevin Lane Keller, 2016. Marketing Management, $15^{\text {th }}$ Edition, Pearson Education,Inc.

[10] Alhassan G. Mumuni, Karen M. Lancendorfer, Kelley A. O’Reilly, Amy MacMillan. 2019. Antecedents of consumers' reliance on online product reviews. Journal of Research in Interactive Marketing, https://doi.org/10.1108/JRIM-11-2017-0096

[11] Briliana, V; Deitiana, T.; Ruswidiono, W. 2019. How Millennial Travelers Are Forcing Indonesian Tourism to Go Digital. International Journal of Business, Economics and Law, Vol. 19, Issue 2 (August) https://www.ijbel.com/wpcontent/uploads/2019/09/BU S_46.pdf

[12] Oliveira Tiago, Benedita Araujo, Carlos Tam. 2020. Why do people share their travel experiences on social media? Tourism Management.

https://doi.org/10.1016/j.tourman.2019.104041

[13] Liu, Z. and Park, S. 2015. What makes a useful online review? Implication for travel product websites, Tourism Management, Vol. 47, pp. 140-151.

[14] Rivera, M.,Gregory, A.,Cobs L., 2015. Mobile application for the timeshare industry: The influence of technology experience, usefulness, and attitude on behavioral intentions. J. Hosp. Tourism Technol. 6 (3), 242-257.

[15] Briliana, V. \& Prasetio, A. 2018. Some Antecedents and Effects of using Mobile Apps in Tourism Marketing. Proceedings of the 7th International Conference on Entrepreneurship and Business Management - ICEBM Untar, ISBN 978-989758-363-6, pages 270-275. DOI:

$10.5220 / 0008491702700275$

[16] Lee, S., 2018. Enhancing customers; continued mobile app use in the service industry. Journal of Services Marketing, 32(6). 680-691

[17] Ian Phau Vanessa Quintal Chris Marchegiani Sean Lee. 2016. Looking beyond pasta and pizzas: Examining personal and historical nostalgia as travel motives. International Journal of Culture, Tourism and
Hospitality Research, Vol. 10, Issue 3, pp. 296 - 309 http://dx.doi.org/10.1108/IJCTHR-07-2015-0073

[18] Havlena, W.J. and Holak, S.L. 1991. The good old days: observations on nostalgia and its role in consumer behavior, Advances in Consumer Research, Vol. 18 No. 1, pp. 323-329.

[19] Stern, B.B. 1992. Historical and personal nostalgia in advertising text: the fin siècle effect. Journal of Advertising, Vol. 21 No. 4, pp. 11-22.

[20] Sellick, M.C. 2004. Discovery, connection, nostalgia: key travel motives within the senior market. Journal of Travel \& Tourism Marketing, Vol. 17 No. 1, pp. 55-71.

[21] Briliana, V. 2018. Creating Value through Authenticity and Social eWOM: Evidence from Authentic Traditional Yogyakarta Cuisines. DOI: $10.5220 / 0008488500810086$ in Proceedings of the 7th International Conference on Entrepreneurship and Business Management (ICEBM Untar 2018), pages 8186 ISBN: 978-989-758-363-6

[22] Jang,S. and Park, K. 2012. Effects of ethnic authenticity: Investigating Korean restaurant customers in the U.S., International Journal of Hospitality Management, No. 31, pp. 990-1003.

[23] Bessiere, J., 1998. Local development and heritage: Traditional food and cuisine as tourist attractions in rural areas. European Society for Rural Sociology, 38(1), 21-34. doi: 10.1111/1467-9523.00061

[24] Jang, S. and Namkung, Y. 2011. Effects of authentic atmospherics in ethnic restaurants: investigating Chinese restaurants, International Journal of Contemporary Hospitality Management, Vol. 23 No. 5, pp. 662-680.

[25] Y. Ram, P. Bjork, A. Weidenfeld. 2016. Authenticity and place attachment of major visitor attractions. Tourism Management 52 (2016) 110-122. http://dx.doi.org/10.1016/j.tourman.2015.06.010

[26] Anderson, J. and Gerbing, D. 1988. Structural Equation Modeling in Practice: A Review and Recommended Two-Step Approach. Psychological Bulletin, 103, 411-423. http://dx.doi.org/10.1037/00332909.103.3.411

[27] Hair, J. F., Hult, T. M., Christian M., and Sarstedt, M.2017. A Primer on Partial Least Squares Structural Equation Modelling. Washington DC: SAGE Publications. 